\title{
A NEW SYSTEM OF SET-VALUED VARIATIONAL INCLUSIONS WITH $H$-MONOTONE OPERATORS
}

\author{
WEN-YONG YAN, YA-PING FANG AND NAN-JING HUANG
}

\begin{abstract}
The purpose of this paper is to introduce and study a new system of set-valued variational inclusions with $H$-monotone operators in Hilbert spaces. By using the resolvent operator method associated with $\mathrm{H}$-monotone operator due to Fang and Huang, we construct a new iterative algorithm for solving this kind of system of set-valued variational inclusions. We also prove the existence of solutions for the system of set-valued variational inclusions and the convergence of iterative sequences generated by the algorithm.
\end{abstract}

Mathematics subject classification (2000): 49J40, 47H10.

Key words and phrases: $H$-monotone operator, resolvent operator technique, system of set-valued variational inclusion, iterative algorithm.

\section{REFERENCES}

[1] S. ADLY, Perturbed algorithm and sensitivity analysis for a general class of variational inclusions, J. Math. Anal. Appl. 201 (1996), 609-630.

[2] R. AHMAD AND Q. H. ANSARI, An iterative algorithm for generalized nonlinear variational inclusions, Appl. Math. Lett. 135 (2000), 23-26.

[3] Y. J. CHO, Y. P. FANG, N. J. HUANG AND H. J. HwANG, Algorithms for systems of nonlinear variational inequalities, J. Korean Math. Soc. 41 (2004), 489-499.

[4] Y. P. FANG AND N. J. HUANG, H -Monotone operator and resolvent operator technique for variatonal inclusions, Appl. Math. Comput. 145 (2003), 795-803.

[5] Y. P. FANG AND N. J. HUANG, Existence results for systems of strongly implicit vector variational inequalities, Acta Math. Hungar. 103(2004), 265-277.

[6] Y. P. FANG AND N. J. HUANG, $H$-monotone operators and system of variational inclusions, Commun. Appl. Nonlinear Anal. 111 (2004), 93-101.

[7] N. J. HUANG, Generalized nonlinear variatonal inclusions with noncompact valued mappings, Appl. Math. Lett. 9(3) (1996), 25-29.

[8] N. J. HUANG, Mann and Ishikawa type perturbed iterative algorithms for generalized nonlinear implicit quasi-variational inclusions, Comput. Math. Appl. 3510 (1998), 1-7.

[9] N. J. HuANG, A new completely general class of variational inclusions with noncompact valued mappings, Comput. Math. Appl. 3510 (1998), 9-14.

[10] N. J. HUANG AND Y. P. FANG, Fixed point theorems and a new system of multivalued generalized order complementarity problems , Positivity 7 (2003), 257-265.

[11] G. Kassay and J. Kolumbàn, System of multi-valued variational inequalities, Publ. Math. Debrecen 56 (2000), 185-195.

[12] G. KASSAY, J. KOlumbán AND Z. PÁLES, Factorization of Minty and Stampacchia variational inequality system, European J. Operational Research 143(2) (2002), 377-389.

[13] J. K. KIM AND D. S. KIM, A new system of generalized nonlinear mixed variational inequalities in Hilbert spaces, J. Convex Anal. 11 (2004), 117-124.

[14] C. H. LEE, Q. H. ANSARI AND J. C. YAO, A perturbed algorithm for strongly nonlinear variational-like inclusions, Bull. Austral. Math. Soc. 62 (2000), 417-426. 
[15] L. W. LIU AND Y. Q. LI, On generalized set-valued variational inclusions, J. Math. Anal. Appl. 2611 (2001), 231-240.

[16] S. B. NADLER, Muliti-valued contraction mappings, Pacific J. Math. 30 (1969), 475-488.

[17] R. U. VERMA, Iterative algorithms and a new system of nonlinear quasivariational inequalities, Adv. Nonlinear Var. Inequl. 41 (2001), 117-124.

[18] R. U. VERMA, Projection methods, algorithms, and a new system of nonlinear variational inequalities, Comput. Math. Appl. 41 (2001), 1025-1031.

[19] R. U. VERMA, Generalized system for relaxed coercive variational inequalities and projection methods, J. Optim. Theory Appl. 121 (2004), 203-210.

[20] E. ZEIDLER, Nonlinear Functional Analysis and its Applications II: Monotone Operators, SpringerVerlag, Berlin, 1985. 